\title{
Hypersensitivity to conventional and to nickel-free orthodontic brackets
}

\author{
Hipersensibilidade a bráquetes ortodônticos \\ convencionais e a bráquetes "nickel-free"
}

\begin{abstract}
Mariele Cristina Garcia Pantuzo(a) Elton Gonçalves Zenóbio(b) Helenice de Andrade Marigo(c) Madelon Aparecida Fernandes Zenóbio ${ }^{(d)}$
\end{abstract}

(a) Master's Degree in Orthodontics; (b) PhD, Professor of Periodontics; (c) PhD, Professor of Stomatology - School of Dentistry, Pontifical Catholic University of Minas Gerais.

(d) $\mathrm{PhD}$, Professor of Stomatology, Federal University of Minas Gerais.

\author{
Corresponding author: \\ Elton Gonçalves Zenóbio \\ Pontifícia Universidade Católica de \\ Minas Gerais \\ Programas de Pós-Graduação \\ em Odontologia \\ Av. Dom José Gaspar, 500, Prédio 46, \\ Coração Eucarístico \\ Belo Horizonte - MG - Brazil \\ CEP: 30535-610 \\ E-mail: zenobio@pucminas.br
}

Received for publication on Dec 18, 2006 Sent for alterations on Feb 23, 2007

Accepted for publication on Apr 09, 2007

\begin{abstract}
The aim of this study was to evaluate the allergenic potential of orthodontic brackets, comparing the cutaneous sensitivity provoked by metals present in conventional metallic brackets to that provoked by brackets with a low concentration of nickel, known as "nickel-free". A sample was selected from 400 patients undergoing treatment in the orthodontic clinic of the Pontifical Catholic University of Minas Gerais (Belo Horizonte, MG, Brazil), in the period from the beginning of 2002 to the end of 2003. A cutaneous sensitivity patch test containing $5 \%$ nickel sulphate was used in 58 patients $(30$ males and 28 females), aged between 11 and 30, which were using fixed appliances with Morelli ${ }^{\circledR}$ brackets in both arches. In a second phase, 30 days later, a comparative test of cutaneous sensitivity was applied to the whole sample with two types of test specimens, in the form of a disc. Two alloys were tested: discs composed of the alloy used in the construction of conventional brackets and discs composed of a nickel-free alloy. The internal part of the forearm was chosen for testing, and 20 test specimens of each experiment (corresponding to the twenty brackets of a complete fixed appliance) were applied. Of the 58 patients evaluated, 16 patients were sensitive to the patch test with $5 \%$ nickel sulphate. Out of these 16 patients, 12 developed an allergic reaction to experiment 1 (test specimen with nickel), while in experiment 2 , only 5 patients showed sensitivity to that sample. The McNemar test revealed that the nickel-free test specimens provoked less allergic reaction when compared with the conventional alloy $(\mathrm{p}=0.016)$.

Descriptors: Hypersensitivity; Nickel; Stainless steel; Orthodontics, corrective.
\end{abstract}

Resumo: Este trabalho teve como objetivo avaliar a capacidade alergênica provocada pelos bráquetes ortodônticos, comparando a sensibilidade cutânea provocada pelos metais presentes nos bráquetes metálicos convencionais com a provocada por bráquetes com baixa concentração de níquel ("nickel-free”). A amostra foi selecionada dos 400 pacientes em tratamento da clínica de Ortodontia da Pontifícia Universidade Católica de Minas Gerais (Belo Horizonte, MG, Brasil), no período compreendido entre o início de 2002 e o final de 2003. A amostra consistiu de 58 pacientes ( 30 homens e 28 mulheres), com idades variando de 11 a 30 anos, os quais eram portadores de aparelho ortodôntico fixo Morelli ${ }^{\circledast} \mathrm{em}$ ambos os arcos. Estes pacientes foram diagnosticados quanto à sensibilidade ao níquel, por meio da aplicação do "patch test" com sulfato de níquel a 5\%. Em uma segunda fase, trinta dias após o "patch test", comparou-se a sensibilidade cutânea provocada pelos metais presentes nos bráquetes convencionais e nos "Nickel Free", por meio de um teste de sensibilidade cutânea utilizando-se dois tipos de corpos-de-provas, em formato de disco, com a mesma composição destes bráquetes. A área de eleição para realização deste teste foi a parte interna do antebraço, sendo aplicados vinte corpos-de-prova de cada experimento (referente a uma boca completa de bráquetes). Dos 58 pacientes avaliados, 16 deles foram sensíveis ao "patch test" com sulfato de níquel a 5\%. Dentre estes 16 pacientes, 12 deles desenvolveram reação alérgica ao Experimento 1 (corpo-de-prova com níquel), enquanto que no Experimento 2 (corpo-de-prova "Niquel Free") apenas 5 pacientes apresentaram sensibilidade a esta amostra. O teste de McNemar revelou que os corpos-de-prova "nickel-free" provocaram menor reação alérgica quando comparados aos convencionais ( $\mathrm{p}=0.016$ ).

Descritores: Hipersensibilidade; Níquel; Aço inoxidável; Ortodontia corretiva. 


\section{Introduction}

Contact with nickel is one of the most frequent causes of contact dermatitis. ${ }^{2,6,12,20,26,27}$ This metal is found in the environment and potential contact comes from water, air, some foods and from medical and orthodontic devices, as well as jewellery and, increasingly, body piercing. ${ }^{3,11,24}$

Nickel alloys are widely used in the orthodontic clinic in brackets, wires, bands and other orthodontic accessories. Nickel has been incorporated into the majority of these alloys to increase the corrosion resistance and reduce oxidation at high temperatures. ${ }^{25}$ However, when these alloys are in contact with the oral environment, they are subject to corrosion and liberate metallic ions into the oral cavity, among them nickel ions. ${ }^{4,5,25}$

As a result, research has been undertaken with the aim of evaluating nickel ion liberation resulting from corrosion of orthodontic devices in contact with the oral cavity. ${ }^{1,6,28}$

The literature shows that nickel is potentially allergenic, and capable of provoking a late-phase, type IV hypersensitivity reaction, that presents signs in the oral cavity including gingival overgrowth, angular cheilitis and labial desquamation. ${ }^{7,16,19,24}$ There are reports in the literature that allergic reactions to nickel are frequently associated with reactions to other metals, among them chrome and cobalt. . $^{4,5,9,13,28}$

Studies have shown that nickel ion liberation from orthodontic appliances is capable of provoking allergic reactions in the oral cavity. ${ }^{17,18}$ Many authors have reported a directly proportional relationship between the concentration of nickel ions liberated and the concentration of nickel in the alloy. This situation has provoked the metallurgical industry to support research seeking hypoallergenic orthodontic accessories. ${ }^{6,9,14,15,26,28}$ Accessories made with low concentrations of nickel, known as nickelfree brackets, have appeared as a material capable of liberating lower quantities of nickel ions, which suggests a lower sensitivity and is therefore ideal for patients hypersensitive to this metal. ${ }^{12,14,23,25,26,28}$ As a result of these clinical findings and reports in the literature, this study had the objective of comparing the cutaneous sensitivity provoked by conventional metallic brackets to that provoked by brackets with low concentrations of nickel, known as nickel-free brackets.

\section{Material and Methods}

From 400 patients undergoing treatment in the orthodontic clinic of the Pontifical Catholic University of Minas Gerais (Belo Horizonte, MG, Brazil) in the period from the beginning of 2002 to the end of 2003, a sample was selected of 58 patients (30 male and 28 female), aged between 11 and 30 years. All patients used total fixed appliances with More$11 i^{\circledast}$ brackets (Dental Morelli Ltda. - Sorocaba, SP, Brazil) in both arches, showed no systemic alterations, and did not use any medication.

In the first phase, all patients were questioned concerning a personal and/or family history of previous allergy to metal during medical history taking, and were then submitted to cutaneous testing using a patch test containing $5 \%$ nickel sulphate (Substance 27 - FDA Allergenic Ltda., Rio de Janeiro, RJ, Brazil). The patch test was applied to the upper arm of each individual, following the technique described by Marks, Deleo ${ }^{20}$ (1992), for a period of 48 hours. The reading scale used was proposed by the International Contact Dermatology Research Group (ICDRG). In the second phase, 30 days later, a comparative test of cutaneous sensitivity was applied to the whole sample with two types of test specimens, in the form of a disc, with a diameter of $2 \mathrm{~mm}$ (Chart 1).

In each individual, 20 test specimens of each Test were applied in the same area (with reference to the twenty brackets of a complete fixed appliance), on the internal part of the forearm for 48 hours. The method of reading was the same as that used for the patch test. Test 1 was applied in the right forearm and Test 2, in the left forearm. All procedures used were conducted according to the ethic standards set

Chart 1 - Testing of test specimens.

\begin{tabular}{l|l}
\hline \multicolumn{1}{c|}{ Test 1} & \multicolumn{1}{c}{ Test 2} \\
\hline $\begin{array}{l}\text { Test specimens with nickel } \\
\text { (composition similar to } \\
\text { that of a conventional } \\
\text { bracket) }\end{array}$ & $\begin{array}{l}\text { Test specimens with a low } \\
\text { concentration of nickel (composition } \\
\text { similar to that of a nickel-free } \\
\text { bracket) }\end{array}$ \\
\hline
\end{tabular}


by the Research in Humans Committee, Pontifical Catholic University of Minas Gerais, and according to the Helsinki Declaration (1975), reviewed in 1983.

The sensitivity results were statistically analysed using the McNemar test and Fisher's exact test.

\section{Results}

Of the 58 patients evaluated, 16 patients $(27.6 \%)$ were sensitive to nickel as measured by a positive patch test (Graph 1). In relation to a previous history of allergy to metals, of the 42 patients $(72.4 \%)$ which were negative to the patch test, only one patient $(2.4 \%)$ reported a positive history, while in the group of 16 patients $(27.6 \%)$ which were positive to the patch test, this number raised to 6 patients $(37.5 \%)$. This difference was signifi-

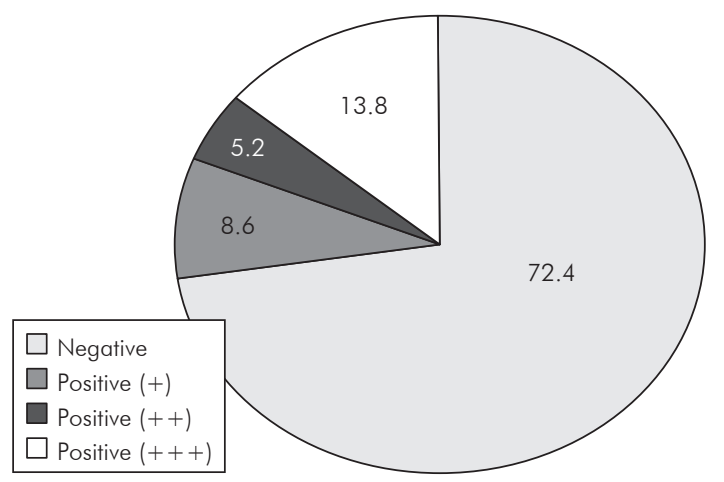

Graph 1 - Classification of patients according to patch test results.

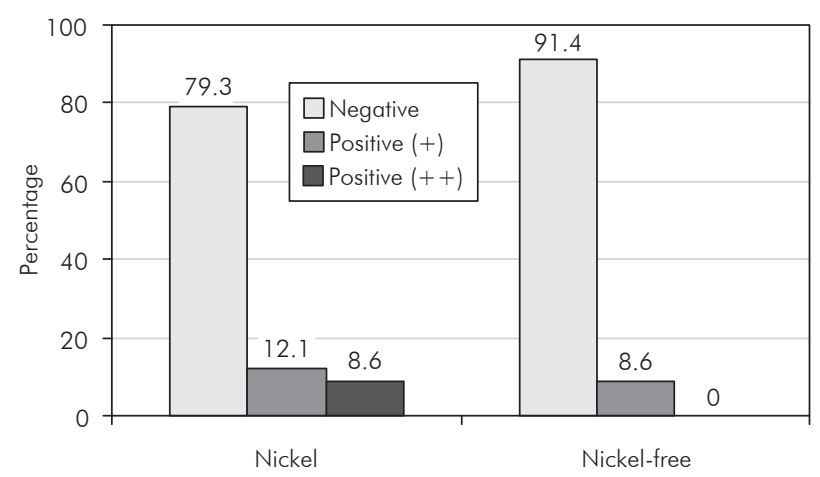

Graph 3 - Classification of patients according to skin testing with test specimens. (Note: $p=0.016$, McNemar test.) cant, as revealed by Fisher's exact test (Graph 2). In relation to an allergic response to the test specimens, 12 patients $(20.7 \%)$ developed allergy to Test 1 , of which 7 patients displayed a weak positive reaction $(+)$, while the other 5 displayed a strong positive reaction (++). In Test 2 , only 5 patients $(8.6 \%)$ showed sensitivity to the test specimens (a weak positive response, +), demonstrating a significant reduction $(\mathrm{p}=0.016, \mathrm{McNemar}$ test) in comparison to the results of the other Test (Graph 3).

In the group of 16 patients sensitive to the patch test, 12 of them $(75 \%)$ showed sensitivity to the test specimen of Test 1 and, among them, 5 patients (31\%) reacted to the test specimen in Test 2 as well as to that in Test 1 , with a significant difference ( $\mathrm{p}=0.016, \mathrm{McNemar}$ test $)$ (Graph 4).

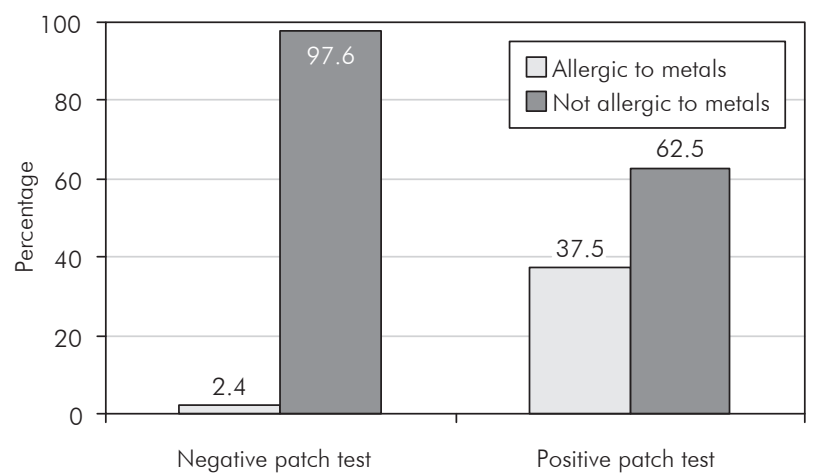

Graph 2 - Classification of patients according to history of allergy to metals with respect to patch test. (Note: $p=0.001$, Fisher's exact test.)

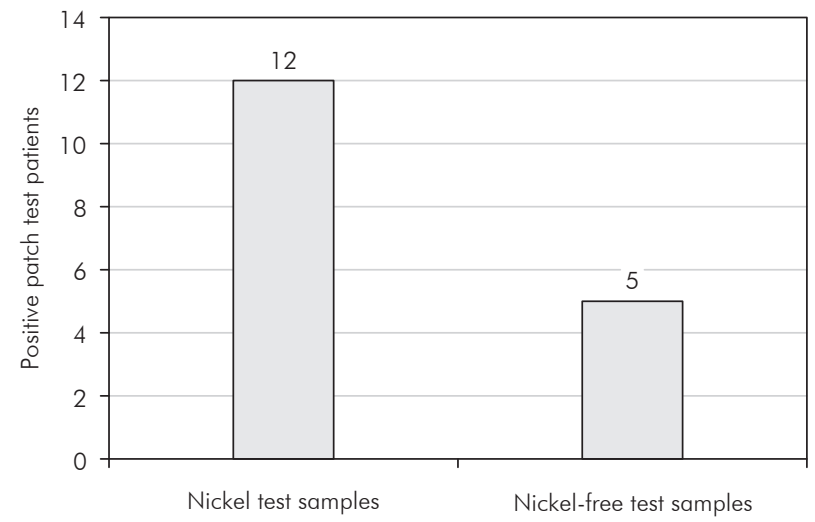

Graph 4 - Patients with a positive patch test and sensitive to the test specimens. (Note: $p=0.016$, McNemar test.) 


\section{Discussion}

The prevalence found in this study of a sensitivity reaction to nickel was $27.6 \%$ of the sample and is in agreement with the results of other studies cited in the literature. ${ }^{2,6} \mathrm{~A}$ positive association was found between a history of allergy to metals and a hypersensitivity reaction to nickel (6 patients $=37.5 \%$, $\mathrm{n}=16)$ similar to that found by Blanco-Dalmau et al. ${ }^{6}$ (1984) and Menezes et al. ${ }^{22}$ (2004). A significant reduction in the allergic response was found when comparing exposure to the two types of test specimens. Only five patients from the whole sample were sensitive to the nickel-free test specimen (Test 2 ), and these patients were positive to both the patch test and the test specimen containing nickel (Test 1). Graph 4 shows that only 12 of the patients with a positive patch test to nickel showed sensitivity to the test specimen containing nickel. The remaining four patients with a positive patch test were therefore false-positive.

Menné et al. ${ }^{23}$ (1987) found similar results, but used alloys which liberated higher levels of nickel ions, provoking a more potent skin reaction.

A possible explanation for all the patients sensitive to the test sample of Test 2 and who were also sensitive in Test 1 may be that the allergic reaction to nickel is often associated with allergies to chrome and cobalt, which are potent allergens present in the composition of the two test specimens. Probably, these five patients were sensitive to nickel as well as to chrome and cobalt, as cited in the work of many authors. ${ }^{4,9,13,22,28}$

\section{References}

1. Ağaoğlu G, Arun T, Izgü B, Yarat A. Nickel levels in the saliva and serum of orthodontic patients. Angle Orthod. 2001;71(5):375-9.

2. Bass JK, Fine H, Cisneros GJ. Nickel hypersensitivity in the orthodontic patient. Am J Orthod Dentofacial Orthop. 1993;103(3):280-5.

3. Bennett BG. Exposure of man to environmental nickel - An exposure commitment assessment. The Science of the total environment. 1982;22(3):203-12.

4. Bergman M. Corrosion in the oral cavity. Potential local and systemic effects. Int Dent J. 1986;36(1):41-4.
In recent years, orthodontic manufacturers have developed new orthodontic accessories that meet the esthetic demand of adult patients and that are safer to their health. ${ }^{7,8}$

There are a number of non-allergic brackets to attend those nickel-sensitive patients, such as the Titanium bracket which is more corrosion-resistant and does not release nickel in the oral cavity. ${ }^{8,10,12}$ Another option are the low nickel concentration brackets, known as nickel-free ${ }^{14,21,28}$ and also ceramic or plastic brackets. The 2205 duplex stainless steel contains much less nickel and could also be used to develop orthodontic accessories with less allergic potential. ${ }^{10,25}$

\section{Conclusions}

1. A significant positive association was found (37.5\%, $p=0.001$, Fisher's exact test) between patients sensitive to nickel and a history of contact allergy, and it is therefore important to include this question when taking a patient's medical history.

2. The nickel-free test specimens provoked a significantly smaller allergic reaction $(\mathrm{p}=0.016$, McNemar test) in only $31 \%$ of the patients sensitive to nickel.

3. The allergenic potential of other metals such as chrome and cobalt should be emphasised, and a response to them occurring simultaneously with a response to nickel should be considered since they are all constituents of orthodontic accessories.

5. Bergman M, Bergman B, Söremark R. Tissue accumulation of nickel released due to electrochemical corrosion of nonprecious dental casting alloys. J Oral Rehabil. 1980;7(1):32530.

6. Blanco-Dalmau L, Carrasquillo-Alberti H, Silva-Parra J. A study of nickel allergy. J Prosthet Dent. 1984;52(1):116-9.

7. Burden DJ, Eedy DJ. Orthodontic headgear related to allergic contact dermatitis: a case report. Br Dent J. 1991;170:4478 .

8. Deguchi T, Ito M, Obata A, Koh Y, Yamagishi T, Oshida Y. Trial Production of Titanium orthodontic brackets fabricated 
by metal injection molding (MIM) with sintering. J Dent Res. 1996;75(7):1491-6.

9. Eliades T, Athanasiou EA. In vivo aging of orthodontic alloys: implications for corrosion potential, nickel release, and biocompatibility. Angle Orthod. 2002;72(3):222-37.

10. Eliades T, Eliades G, Brantley WA. Orthodontic Brackets. In: Brantley WA, Eliades T. Orthodontic materials: scientific and clinical aspects. New York: T. Thieme; 2001. p. 143-71.

11. Greppi AL, Smith DC, Woodside DG. Nickel hypersensitivity reactions in orthodontic patients: a literature review. Univ Tor Dent J. 1981;3(1):11-4.

12. Hamula DW, Hamula W, Sernetz F. Pure Titanium Orthodontic Brackets. J Clin Orthod. 1996;30(3):140-4.

13. Hildebrand HF, Veron C, Martin P. Nickel, Chromium, Cobalt dental alloys and allergic reactions: An overview. Biomaterials. 1989;10(8):545-8.

14. Huang T, Yen C, Kao C. Comparison of ion release from new and recycled orthodontic brackets. Am J Orthod Dentofacial Orthop. 2001;120(1):68-75.

15. Hwang C, Shin J, Cha J. Metal release from simulated fixed orthodontic appliances. Am J Orthod Dentofacial Orthop. 2001;120(4):383-91.

16. Jacobsen N, Hensten-Pettersen A. Occupational health problems and adverse patient reactions in orthodontics. Eur J Orthod. 1989;11(3):254-64.

17. Janson GR, Dainesi EA, Consolaro A, Woodside DG, Freitas MR. Nickel hypersensitivity reaction before, during, and after orthodontic therapy. Am J Orthod Dentofacial Orthop. 1998;113(6):655-60.

18. Kerosuo H, Kullaa A, Kerosuo E, Kanerva L, Hensten-Petersen A. Nickel allergy in adolescents in relation to orthodontic treatment and piercing of ears. Am J Orthod Dentofacial Orthop. 1996;109(6):148-54.

19. Marigo M, Nouer DF, Genelhu MCS, Malaquias LCC, Pizziolo VR, Costa ASV et al. Evaluation of immunologic profile in patients with nickel sensitivity due to use of fixed orthodontic appliances. Am J Orthod. 2003;124(1):46-52.

20. Marks JG, Deleo Jr. VA. Contact and occupational dermatology. Saint Louis: Mosby Year Book; 1992.

21. Matasa CG. Attachment Corrosion and its testing. JCO. 1995;XXIX(1):16-23.

22. Menezes LM, Campos LC, Quintão CC, Bolognese AM. Hypersensitivity to metals in orthodontics. Am J Orthod Dentofacial Orthop. 2004;126(1):58-64.

23. Menné T, Brandrup K, Thestrup-Pedersen NK, Veien JR, Andersen F, Yding F et al. Patch test reactivity to nickel alloys. Contact Dermatitis. 1987;16(5):255-9.

24. Park HY, Shearer TR. In vitro release of nickel and chromium from simulated orthodontic appliances. Am J Orthod. 1983;84(2):156-9.

25. Platt JA, Guzman A, Zuccari A, Thornburg DW, Rhodes BF, Oshida Y et al. Corrosion behavior of 2205 duplex stainless steel. Am J Orthod Dentofacial Orthop. 1997;112(1):69-79.

26. Rahilly G, Price N. Nickel allergy and orthodontics. J Orthod. 2003;30(2):171-4.

27. Rycroft RJG, Menné T, Frosch PJ, Lepoittevin JP. Textbook of contact dermatitis. $3^{\text {rd }}$ ed. Berlim: Springer; 2001.

28. Wichelhaus A, Culum T, Sander FG. Investigaciones relacionadas con la composición de la superfície de las aleciones que se utilizan en ortodoncia, con una consideración especial para el porcentaje que contienen de níquel. Rev Esp Ortod. 1997;27:4560. 